\title{
VASSALAK LELETEK A RÓMAI LIMES ERDÉLYI, MAROS MEGYEI SZAKASZÁRÓL (MAROSVÉCS, MIKHÁZA, FELSŐRÉPA). FTIR ÉS XRF SPEKTROSZKÓPIAI JELLEMZÉS.
}

\section{FTIR AND XRF SPECTROSCOPIC CHARACTERIZATION OF IRON SLAGS UNEARTHED ON THE MURES COUNTY SECTOR (TRANSYLVANIA, ROMANIA) OF THE ROMAN LIMES (BRÂNCOVENEŞTI, CĂLUGĂRENI, VĂTAVA)}

\author{
Bitay Enikő ${ }^{1}$, Kacsó Irén ${ }^{2}$, Claudiu Tanaselia ${ }^{3}$, Nyulas Dorottya ${ }^{4}$, Pánczél Szilamér ${ }^{5}$, \\ Veress Erzsébet ${ }^{6}$ \\ ${ }^{I}$ Sapientia Hungarian University of Transylvania, Faculty of Technical and Human \\ Sciences, OP 9 CP 4, 540485, Târgu-Mureş, Romania, Tel.+40-751-016063, \\ ebitay@ms.sapientia.ro \\ ${ }^{2}$ National Institute for Research and Development of Isotopic and Molecular \\ Technologies INCDTIM, OP 5 CP 700, 400293, Cluj, Romania, Tel. +40 745- \\ 645670,iren.kacso@gmail.com \\ ${ }^{3}$ INCDO-INOE 2000 Research Institute for Analytical Instrumentation, 67 Donat \\ str., 400293, Cluj, Romania,Tel. +40-744-670782, claudiu@tanaselia.ro \\ ${ }^{4}$ Babeş-Bolyai University, Faculty of History, 1 Mihail Kogălniceanu str., 400084 \\ Cluj, Romania, Tel+40-743-472555, nydorottya@yahoo.com \\ ${ }^{5}$ Mureş County Museum,.8 Mărăşti str., 540328, Târgu-Mureş, Romania, Tel +40- \\ 721-487661,pszilamer@yahoo.com \\ ${ }^{6}$ Transylvanian Museum Society, OP 1 CP 191, 400750, Cluj, Romania, Tel. +40- \\ 743-119275,veresserzsebet@gmail.com
}

\begin{abstract}
Iron slag probes unearthed at the Brâncoveneşti/Marosvécs, Călugăreni/Mikháza and Vătava/Felsőrépa limes sites were subjected to FTIR spectroscopy in order to approximate their mineralogical composition and respectively surface XRF spectroscopic investigation to characterize their elemental composition and inhomogeneity. The relatively broad IR absorption bands obtained in the spectral domain $2000-400 \mathrm{~cm}^{-1}$ show that the samples are mainly constituted of silicates associated to minor quantities of aluminates and carbonates. In concordance with the expectations and supported by both the FTIR spectroscopic and XRF data the primary mineral phase of the samples is most probably fayalite $\left(\mathrm{Fe}_{2} \mathrm{SiO}_{4}\right)$. The experimental data confirm that when discussing the chemical as well as mineral composition, consideration of the heterogeneity of the samples is mandatory.
\end{abstract}

Keywords: roman iron slags, spectroscopy, FTIR, XRF. 


\section{Összefoglalás}

Marosvécsen (Brâncoveneşti), Mikházán (Călugăreni) és Felsőrépán (Vătava) feltárt vassalak leleteket vizsgáltunk spektroszkópiai módszerekkel (FTIR, XRF). Az FTIR spektrumok 2000-400 cm-1 hullámszám tartományában jellemző módon jelentkező nagy intenzitású, viszonylag széles absorpciós sávok alapján a minták kisebb mennyiségü aluminát és karbonát mellett alapvetően szilikátokból állnak. Mint a röntgen-fluoreszcens analízis adatai mutatják, a fö ásványfázis minden esetben nagy valószínűséggel a fayalit (Fe2SiO4). Az egyes minták elemi összetételére vonatkozó, kézi XRF spektrométerrel több felületi ponton nyert adatok ugyanakkor arra utalnak, hogy mind a kémiai, mind az ásványtani következtetések levonásánál tekintettel kell lenni a salakok erősen heterogén jellegére.

Kulcsszavak: Römai vassalak, spektroszkópia, FTIR, XRF.

\section{Bevezetés}

A limes a Római Birodalom mintegy ötezer kilométer hosszú, három kontinensre kiterjedő megerősített határvonala. A Maros, a Felső-Nyárád és a Kis-Küküllö mentét észak-dél irányban átszelö Maros megyei limes-szakasz a II. sz. elején épült ki, és mintegy 150 évig védte Dacia, majd Dacia Superior tartomány, és egyben a Birodalom keleti határát. Az általunk vizsgált vassalak-leletek az itt állomásoztatott segédcsapatok marosvécsi és mikházi táborának területén, a szomszédságukban létrejött katonai településen (vicus), valamint a felsörépai őrtoronynál végzett feltárásokból származnak, ahol a II.-III. században helyi kovácsmühely is müködhetett [1,2]. Az eddigi kutatások során csak kovácsmühelyre utaló leletanyag került elö, kohómaradványok nem bukkantak fel (a mikházi vicusban nagymennyiségü vassalak mellett számos vastárgyat, Felsőrépán kovácsszerszámokat is találtak).

\section{Kísérleti rész}

\subsection{A salakminták rövid jellemzése}

A vizsgálatra kiválasztott 11 vassalak mintából négy Marosvécsről származott (B1-B4), hat Mikházáról (C1-C6) és egy Felsőrépáról (V).
A B1-B4, C3 és C6 minta szivacsos, könnyü, erősen buborékos, habkőszerü. A B2 és B3 különösen könnyen morzsolható (málló). Heterogének, a szürkés C3 minta kivételével felületükön vöröses, feketés, agyagos-sárgás zónák és üveges részek láthatók, beágyazódott fekete kristályokkal (magnetit), apróbb-nagyobb fémcseppekkel (vas), egyeseken fehéres foltokkal (karbonátok). A buborékok mélye általában feketés. A B3 mintán sárga fémcseppek is vannak (arany).

A C1, C2 és C4 hasonlóan heterogén, de szerkezetük tömörebb, keményebbek, sokkal nehezebben morzsolhatók, belsejük jellemzően sötétszürke-feketés.

A kemény, tömör C5 3-4 mm vastag külső terrakotta héja alatt 3-4 mm vastag fekete réteg burkolja a terrakotta belsőt. A különösen kemény $\mathrm{V}$ minta esetében a feketés külső réteg alatt a belső rész szintén terrakotta színü, nagy fekete zárvánnyal.

\subsection{A minták vizsgálata. Eredmények.}

$\mathrm{Az}$ achátmozsárban porított mintákon felvett FT-IR spektrumok JASCO FT-IR6100 spektrométerrel készültek, $\mathrm{KBr}$ pasztillákon, $1 \mathrm{~cm}^{-1}$ felbontással, a 4000-400 $\mathrm{cm}^{-1}$ hullámszám tartományban. A mintavételezés a külső rétegből és a mintabelsőből külön történt, a mintákat előkészítő hőkezelésnek nem vetettük alá.

A felületi elemi összetétel jellemzésére végzett $\boldsymbol{X R F}$ spektrometriás mérésekhez 
Vassalak leletek a római limes erdélyi, Maros megyei szakaszáról (Marosvécs, Mikháza, Felsörépa). FTIR és XRF spektroszkópiai jellemzés

INNOV-X Alpha-6500 kézi spektrométert használtunk. Mérési feltételek: gerjesztési paraméterek $35 \mathrm{kV}$ és $15 \mu \mathrm{A}$, PIN Si detektor, Be ablak, 3 mm szürö, mérőfelület mérete $2 \mathrm{~mm}^{2}$. A mérések minden esetben a minta három különböző, jellemzőként megítélt pontján történtek.

$\mathrm{Az}$ FT-IR spektrumok segítségével következtethetünk a salakok keletkezése és eltemetődése során bekövetkező átalakulási folyamatokra (redox folyamatok, szerkezeti átalakulások, rehidratáció, mállás, egyes elszennyeződések): $3700-3000 \mathrm{~cm}^{-1}$ között jelentkeznek a szabad és kötött $\mathrm{OH}$ jellemző sávjai, 1000-1100 cm $\mathrm{cm}^{-1}$ közötti maximummal pedig egy nagy intenzitású, széles, közel szimmetrikus abszorpciós sáv utalhat a kristályos szilikát szerkezet részleges szerkezeti rendezetlenségére (a salakolvadék lehülésekor való nem teljes kialakulásra vagy utólagos degradálódásra).
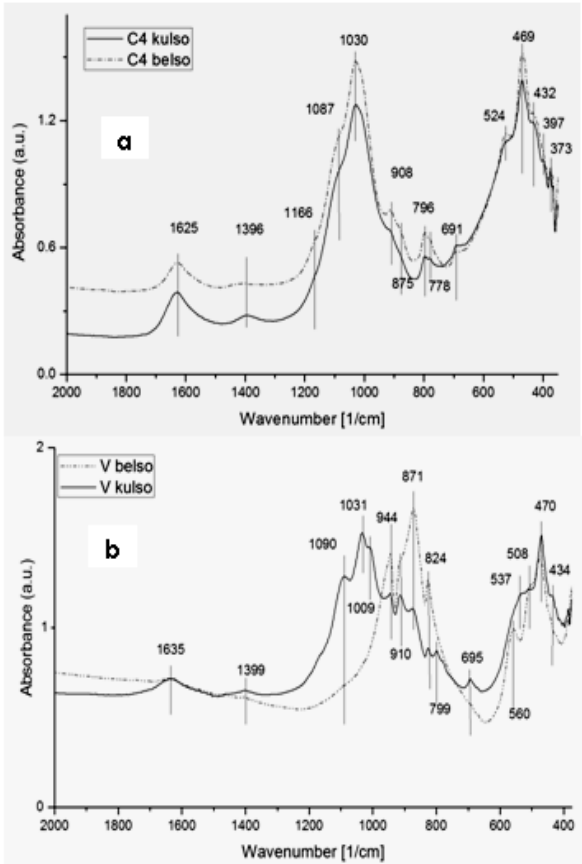

1. ábra. (a).A 2000-400 $\mathrm{cm}^{-1}$ hullámszám tartományban általánosan jellemzö
FT-IR spektrumok.. (b). A V salakminta FT-IR spektrumai.

Tekintettel arra, hogy a 4000-2000 $\mathrm{cm}^{-1}$ spektrumtartomány a minták (egyelöre) nem eléggé tisztázott környezeti körülmények közötti hosszas eltemetettsége következtében nem értelmezhető kielégítő módon, a jelen dolgozatban csak a 2000-400 $\mathrm{cm}^{-1}$ tartományt vettük figyelembe.

A kézi XRF spektrométer $\mathrm{Ca}-\mathrm{U}$ tartományra korlátozott mérési lehetőségei miatt a vassalakok általánosan ismert fó elem-összetevői közül az Al, Si, Mg, K nem mérhető. A valószínü ásványösszetételek meghatározásához ezért a mért elemkoncentrációk mellett figyelembe vettük a szakirodalmi adatokat is [3,4]. Az FT-IR spektrumvonalak hozzárendelésében a feltételezett ásványi komponensek RRUFF adatbázisban levő referencia spektrumait használtuk (https://rruff-2.geo.arizona.edu/).

1. táblázat. .A mikházi minták (C1-C6) fö IR elnyelési frekvenciái $\left(2000-400 \mathrm{~cm}^{-1}\right)$.

\begin{tabular}{|c|c|c|c|c|c|c|}
\hline C1 & C2 & C3 & C4 & C5 & C6 & Hozzárend elések \\
\hline 1631 & 1627 & 1630 & 1625 & 1620 & 1630 & $\begin{array}{l}-\mathrm{OH} \\
\mathrm{FeO}(\mathrm{OH}) 1660\end{array}$ \\
\hline 1400 & 1394 & $1394 \mathrm{sh}$ & 1396 & 1398 & 1401 & $\mathrm{CO}_{3}$ \\
\hline & & $1167 \mathrm{sh}$ & $1166 \mathrm{sh}$ & & $1165 \mathrm{sh}$ & $\mathrm{SiO}_{4} 1100-900,470-460$ \\
\hline $1090 \mathrm{sh}$ & $1094 \mathrm{sh}$ & $1076 \mathrm{sh}$ & $1087 \mathrm{sh}$ & 1084 & $1080 \mathrm{sh}$ & SiO2 $1172,1150,1084$ \\
\hline 1026 & 1025 & 1045 & 1030 & & 1023 & $\begin{array}{l}\mathrm{FeO}(\mathrm{OH}) 1105,1084,940 \\
\mathrm{Fe}, \mathrm{O}, 1100\end{array}$ \\
\hline 908 & $906 \mathrm{sh}$ & $913-876$ & 908 & & 913sh & $\mathrm{PO}_{4} 1100-1000$ \\
\hline & & & 875 & 882 & & $\mathrm{CO}, 1450-1410 ; 880-860 ; 720-680$ \\
\hline 794 & 789 & $\begin{array}{l}794 \\
776\end{array}$ & $\begin{array}{l}796 \\
778\end{array}$ & $\begin{array}{l}796 \\
779\end{array}$ & $\begin{array}{l}796 \\
778\end{array}$ & $\begin{array}{l}\mathrm{SiO}_{2} 798-780, \\
\mathrm{FeO}(\mathrm{OH}) 803,672\end{array}$ \\
\hline 606 sh & 524 sh & 524 & 524 & 526 & $526 \mathrm{sh}$ & $\mathrm{SiO}_{2} 612,462$, \\
\hline $\begin{array}{l}565 \text { sh } \\
469\end{array}$ & & $\begin{array}{l}462 \\
421\end{array}$ & $\begin{array}{l}469 \\
462 \text { sh }\end{array}$ & $\begin{array}{l}467 \\
435\end{array}$ & $\begin{array}{l}471 \\
421\end{array}$ & $\begin{array}{l}\mathrm{Fe}_{2} \mathrm{O}, 630,550,417 \\
\mathrm{FeO}(\mathrm{OH}) 578,470,410\end{array}$ \\
\hline $424 \mathrm{sh}$ & & & & & & $\mathrm{HCO}, 710-690,665-655$ \\
\hline
\end{tabular}

2. táblázat. .A marosvécsi és felsőrépai salakok (B1-B4 és V) jellemzö IR elnyelési frekvenciái $\left(2000-400 \mathrm{~cm}^{-1}\right)$.

\begin{tabular}{|c|c|c|c|c|c|c|}
\hline \multirow{2}{*}{ B1 } & \multirow{2}{*}{ B2 } & \multirow{2}{*}{ B3 } & \multirow{2}{*}{ B4 } & \multicolumn{2}{|r|}{ v } & \multirow{2}{*}{ Hozzárend elések } \\
\hline & & & & kulso & belso & \\
\hline 1631 & 1634 & 1630 & 1627 & 1635 & 1635 & $\begin{array}{l}-\mathrm{OH} \\
\mathrm{FeO}(\mathrm{OH}) 1660\end{array}$ \\
\hline 1394 & - & $1400 \mathrm{w}$ & 1400 & 1399 & $1399 \mathrm{sh}$ & $\mathrm{CO}_{3}$ \\
\hline $1167 \mathrm{sh}$ & & 1165 sh & 1161 sh & $1166 \mathrm{sh}$ & & $\mathrm{SiO}+1100-900,470-460$ \\
\hline $\begin{array}{l}1087 \mathrm{sh} \\
1032\end{array}$ & $\begin{array}{l}1091 \text { sh } \\
1041 \text { sh }\end{array}$ & $\begin{array}{l}1087 \\
1030\end{array}$ & $\begin{array}{l}1086 \text { sh } \\
1033\end{array}$ & $\begin{array}{l}1090 \\
1031\end{array}$ & & $\begin{array}{l}\text { IIO } 21172,1150,1084 \\
\text { FeO }(\mathrm{OH}) 1105,1084,940\end{array}$ \\
\hline $1007 \mathrm{sh}$ & 991 sh & - & 1009 sh & 1009 & $944 \mathrm{~s}$ & $\mathrm{Fe}_{2} \mathrm{O}, 1100$ \\
\hline 913 & 890 & 883 & 913sh & $944 \mathrm{w}$ & $910 \mathrm{sh}$ & $P O=1100-1000$ \\
\hline & & & & $\begin{array}{l}910 w \\
871 w\end{array}$ & $\begin{array}{l}871 \mathrm{sh} \\
824 \mathrm{~m}\end{array}$ & $\mathrm{CO}, 1450-1410 ; 880-860 ; 720-680$ \\
\hline 796 & 798 & 794 & 797 & 824 & & $\mathrm{SiO}_{2} 798-780$, \\
\hline 778 & & & 772 & 799 & & $\mathrm{FeO}(\mathrm{OH}) 803,672$ \\
\hline $563 \mathrm{sh}$ & 608 & $606 \mathrm{sh}$ & 522 & $537 \mathrm{sh}$ & 560 & $\mathrm{SiO}_{2} 612,462$ \\
\hline 519 & 462 & 466 & 468 & 470 & 508 sh & $\mathrm{Fe}_{2} \mathrm{O}, 630,550,417$ \\
\hline 469 & 418 & 421 & 430 sh & 434 & 470 & $\begin{array}{l}\mathrm{FeO}(\mathrm{OH}) 578,470,410 \\
\mathrm{HCO}, 710-690,665-655\end{array}$ \\
\hline
\end{tabular}


A vizsgált hullámszám tartományban a salakok külső rétegén és belsején felvett IR spektrumok abszorpciós sávjai gyakorlatilag egybeesnek, egy kivétellel (V salakminta, 1 ábra). A C1-C6 és B1-B4 salakminták elnyelési frekvenciái közel azonosak (1-2 táblázat). A $\mathrm{Fe}$ tartalom alapján minden minta alapvetően fayalitos (3-4 táblázat).

3. táblázat. .A mikházi salakok (C1-C6) elemi összetétele (három mérés átlaga, ppm)

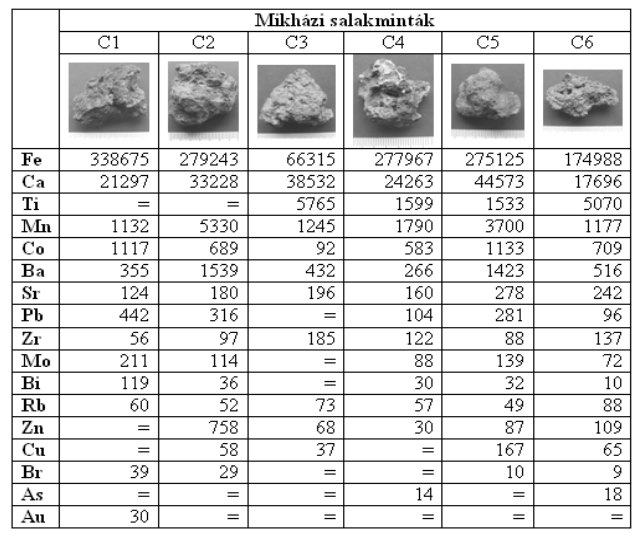

4. táblázat. A marosvécsi és felsörépai salakminták (B1-B4 és V) elemi összetétele (három mérés átlaga, ppm)

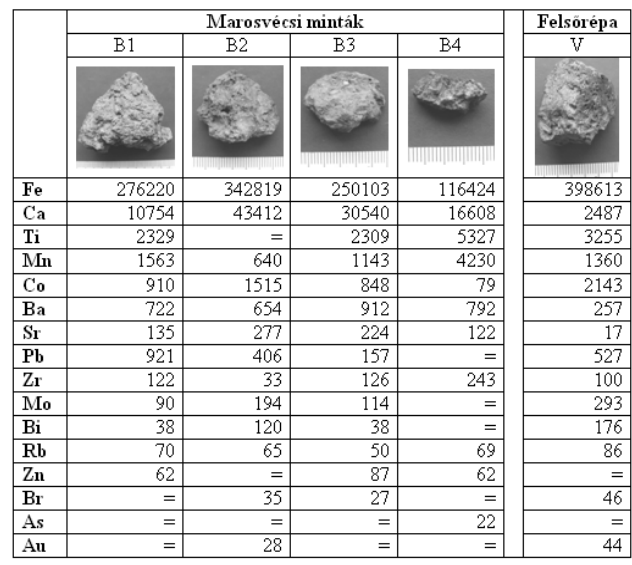

A kisebb eltolódások, egyes jellemző vonalak esetleges hiánya a vizsgált salakok eltérő mikroelemtartalmának, a kristályszerkezetbe való eltérő módon történő beépülésükből következő eltérő koordinációs környezetnek tulajdonítható (3-4 táblázat).

\section{Következtetések}

A 2000-400 $\mathrm{cm}^{-1}$ FTIR spektrumtartományban jellemző módon jelentkező abszorpciós sávok alapján a minták kisebb mennyiségü karbonát (és feltehetően aluminát) mellett alapvetően szilikátokból állnak. Mint az XRF analízis adatai mutatják, a fó ásványfázis minden esetben nagy valószínüséggel a fayalit $\left(\mathrm{Fe}_{2} \mathrm{SiO}_{4}\right)$. A minták elemi összetételére vonatkozó, több felületi ponton nyert adatok ugyanakkor egyes esetekben nagyon különbözők, a levonható kémiai és ásványtani következtetések megtételénél ezért mindig figyelembe kell venni a salakok erösen heterogén jellegét.

\section{Köszönetnyilvánítás}

A kutatást az EME Kutatóintézete Müszaki és kulturális örökségvédelem Erdélyben projektjének keretében a Bethlen Gábor Alap támogatta. A terepi kutatások a PN-II-ID-PCE-2012-4-0618 számú CNCS - UEFISCDI projekt keretében valósultak meg.

\section{Szakirodalmi hivatkozások}

[1] Man N., Cioată D.M.: Archaeological researches in the military vicus from Călugăreni, Marisia XXXII, 2012, 85-99.

[2] Pánczél Sz.P., és mások: Updating our knowledge about the Roman fort from Brâncoveneşti, Mureş county, Marisia XXXII, 2012, 105-115.

[3] Dunster J., Dungworth D., Blacksmith's fuel. The analysis of slags from archaeological and contemporary iron-working, English Heritage Research Report Series 16-2012, NGR: Sz 683 993, 25 pp.

[4] Kramar S., és mások: Mineralogical and geochemical characterization of Roman slag from the archaeological site near Mosnje (Slovenia), Materials and technology 49 (3), 2015, 343-348. 